\title{
Prebiotic activity of garlic (Allium sativum) extract on Lactobacillus acidophilus
}

\author{
Prayogi Sunu ${ }^{1,2}$, Dwi Sunarti ${ }^{1}$, Luthfi Djauhari Mahfudz ${ }^{1}$ and Vitus Dwi Yunianto ${ }^{1}$
}

1. Department of Animal Science, Faculty of Animal and Agricultural Sciences, Diponegoro University, Semarang, Indonesia; 2. Department of Animal Science, Faculty of Animal Science, Boyolali University, Boyolali, Indonesia. Corresponding author: Prayogi Sunu, e-mail: prayogisunusptmsi@gmail.com

Co-authors: DS: dwisunarti@gmail.com, LDM: inditik@yahoo.com, VDY: vitus.dbi@gmail.com Received: 15-08-2019, Accepted: 19-11-2019, Published online: 24-12-2019

doi: www.doi.org/10.14202/vetworld.2019.2046-2051 How to cite this article: Sunu P, Sunarti D, Mahfudz LD, Yunianto VD (2019) Prebiotic activity of garlic (Allium sativum) extract on Lactobacillus acidophilus, Veterinary World, 12(12): 2046-2051.

\begin{abstract}
Aim: The study aimed to examine the ability of prebiotic concentrations to increase the growth of probiotic bacteria in vitro.

Materials and Methods: The probiotics used were Lactobacillus acidophilus and garlic (Allium sativum) extract.

Results: The results showed that garlic can increase the growth of L. acidophilus bacteria with the lowest concentration of $4 \%$ being the most effective $(\mathrm{p}<0.05)$. Increased fructooligosaccharide (FOS) content in garlic can increase the significant growth of $L$. acidophilus as a probiotic bacterium.
\end{abstract}

Conclusion: The results showed that garlic can increase the growth of L. acidophilus bacteria by a minimum of $4 \%$ ( $\mathrm{p}<0.05$ ). Adding FOS to garlic can increase the significant growth of L. acidophilus as a probiotic bacterium.

Keywords: Allium sativum, prebiotics, probiotics, synbiotics.

\section{Introduction}

Antibiotics have been used in the broiler farm industry for decades. Regarding the issue of food security, antibiotic growth promoters (AGPs) are used in most countries [1]. This is related to the potential of AGPs to cause resistance in humans as consumers [2]. Because the ban on AGPs can have a negative impact on the health and productivity of chickens, an alternative substitute for AGPs is needed.

Prebiotics are substrates or undigested food [3] that are selectively fermented by several microflora that live in the digestive tract, such as Lactobacillus and Bifidobacterium, which has a beneficial effect on health [3]. Prebiotics function to stimulate the growth and activity of bacteria that have beneficial effects on the health of the host, especially non-pathogenic bacteria. Gilchrist et al. [1] reported that almost every oligo- and polysaccharide is a prebiotic, but not all carbohydrate foods are prebiotic. According to Kareem et al. [4], there are at least three criteria that need to be fulfilled by a material so that it categorized as prebiotic; (1) it cannot be hydrolyzed nor absorbed at the top of the gastrointestinal tract so that it can reach the colon without structural changes and not be excreted in the feces [5]; (2) it must be selected and fermented by a number of beneficial microflora in the colon to produce a beneficial effect on the host and

Copyright: Sunu, et al. Open Access. This article is distributed under the terms of the Creative Commons Attribution 4.0 International License (http://creativecommons.org/licenses/by/4.0/), which permits unrestricted use, distribution, and reproduction in any medium, provided you give appropriate credit to the original author(s) and the source, provide a link to the Creative Commons license, and indicate if changes were made. The Creative Commons Public Domain Dedication waiver (http://creativecommons.org/ publicdomain/zero/1.0/) applies to the data made available in this article, unless otherwise stated. stimulate the growth of bacteria that actively carry out metabolism [6]; (3) it must be able to convert the colon microflora into compositions that benefit health and selectively stimulate the growth activity of bacteria, such as Lactobacillus in the colon [7].

Allicin and other sulfur components in garlic are active ingredients with antibacterial effects [8]. Garlic has an antibacterial activity that is quite effective at fighting various kinds of Gram-negative and/or positive bacteria [9]. Some bacteria that have been shown to have a high sensitivity to the antibacterial activity of garlic are Staphylococcus, Mycobacteria, and Proteus species [10]. Studies have reported that garlic can be used as a natural prebiotic in feed at a level of $1.0 \%$ to improve growth performance [11]

However, studies on the use of garlic as a synbiotic with Lactobacillus acidophilus are still limited. This research aimed to examine the effect of optimal prebiotic concentration in increasing the growth of probiotic bacteria in vitro.

\section{Materials and Methods}

Ethical approval

This study has been approved by the Animal Ethics Committee of the Faculty of Animal and Agricultural Sciences, Diponegoro University, Semarang, Indonesia.

\section{Garlic extract}

The prepared garlic material $(3 \mathrm{~kg})$ was washed and peeled. After peeling, the garlic was washed again, sliced to a thickness of $1 \mathrm{~cm}$, and placed into a juicer to obtain the extract. The obtained extract was then filtered. After the screening process, the extract was sterilized by pasteurization for $10 \mathrm{~min}$. The extract was stored in a clean container in a dark place 
at a temperature below $20^{\circ} \mathrm{C}$. The amount of extract obtained was recorded and compared to the amount of raw material used.

\section{Synbiotics}

Garlic was extracted at different concentrations ( $2 \mathrm{ml}, 4 \mathrm{ml}, 6 \mathrm{ml}$, and $8 \mathrm{ml}$ ), then added to L. acidophilus at the ratio of 100:1 (ml). Isolates from de Man, Rogosa, and Sharpe (MRS) media supplemented with $20 \%$ glycerol (v/v) and rejuvenated bacterial culture on MRS media were incubated at $37^{\circ} \mathrm{C}$ for $24-48 \mathrm{~h}$ to activate the bacteria, which were then inoculated into an MRS broth media as much as 1 oose and incubated at $37^{\circ} \mathrm{C}$ for $24 \mathrm{~h} \mathrm{[12].}$

\section{Testing of $L$. acidophilus against bile acids}

L. acidophilus was grown anaerobically in a solution of MRS broth at a temperature of $37^{\circ} \mathrm{C}$. Then, $24 \mathrm{~h}$ old liquid stock culture of L. acidophilus was inoculated into MRS broth at a ratio of 2:20 (ml) and incubated at $30^{\circ} \mathrm{C}$ for $18 \mathrm{~h}$. The same procedure was performed to test the bacterial $\mathrm{pH}$, with $\mathrm{pH}$ 1.5-6.5 [13]. One milliliter of culture was taken and placed in $9 \mathrm{ml}$ of MRS broth, the $\mathrm{pH}$ was set to $1.5-6.5$ with $1 \mathrm{~N} \mathrm{HCl}$ and incubated at $30^{\circ} \mathrm{C}$ for $24 \mathrm{~h}$. The number of colonies grown was observed by the planting technique on pour plates containing MRS agar (qualitative analysis).

\section{Testing of $L$, acidophilus against bile salts}

Tests were carried out using the method, namely, by preparing $1 \mathrm{ml}$ of lactic acid bacteria (LAB) in $20 \mathrm{~h}$ old MRS broth added to $9 \mathrm{ml}$ of $0.65 \% \mathrm{NaCl}$. After checking serially, a plate count with the pouring method was performed on MRS agar containing $500 \mathrm{ppm}$ and $1000 \mathrm{ppm}$ Oxygall (Oxoid)/bile salts, with MRS agar as a control. All test mixtures were incubated at $37^{\circ} \mathrm{C}$. Resistance to bile salts was calculated based on the difference in the unit log number of colonies growing in control conditions with bile salt treatments. Observations were made by comparing the number of L. acidophilus: The smaller the difference, the more resistant the tested strains were against bile salts [14].

\section{Viability test of $\boldsymbol{L}$. acidophilus in garlic mixture}

The resistance of $L$. acidophilus in the mixture was calculated using the cup count method [15], $4 \mathrm{~h}$ after mixing. The sample was prepared and homogenized, and $1 \mathrm{ml}$ of each dilution was pipetted to a Petri dish of 12-15 $\mathrm{ml}$. The samples were homogenized by carefully shaking the Petri dishes until they were evenly mixed for seeding. A blank examination was carried out by mixing seeded diluted water for each sample examined and then the mixtures were left to freeze. The Petri dishes are inserted into the incubator and incubated at $35 \pm 10^{\circ} \mathrm{C}$ for $24-48 \mathrm{~h}$. The growth of milky white colonies on each cup contained 25-250 colonies after $48 \mathrm{~h}$. The total plate number of L. acidophilus in $1 \mathrm{~g}$ or $1 \mathrm{ml}$ is calculated by dividing the average number of colonies in the cup with the dilution factor used (accordingly).

\section{Calculation of total LAB in feed}

The calculation of total bacteria was performed by taking a sample of $1 \mathrm{~g}$ and then adding as much as $9 \mathrm{ml}$ of $0.9 \% \mathrm{NaCl}$ solution until homogeneous. Then, the food suspension was placed in a Petri dish and wrapped in aluminum foil and stored for $24 \mathrm{~h}$. The calculation of the number of colonies was performed using a colony counter.

\section{Temperature resistance test}

One colony of bacterial isolates was inoculated into MRS broth media with a mixture of garlic and basal feed and then incubated at a temperature of 50, 60,70 , or $80^{\circ} \mathrm{C}$. The bacterial growth was determined by calculating bacterial colonies with dilution techniques and characterized by the turbidity in the media.

\section{Old feed storage test}

The homogeneous ingredients were evenly sprayed into $100 \mathrm{~g}$ of feed using a spray bottle, dried for $15 \mathrm{~min}$, stored in a closed container (jar) at room temperature $\left(25^{\circ} \mathrm{C}\right)$, and (according to the treatment) stored for $1,2,3$, or 4 days. The numbers of colonies were calculated using a colony counter.

\section{Statistical analysis}

Analysis of the data obtained was performed using Steel and Torrie analysis of variance (ANOVA) if there were differences between treatments as determined by Duncan's multiple range test [16]. The linear model that explains each value of observation using a model proposed by Gherezgihier et al. [16] was as follows:

Information:

$$
Y_{i j}=\mu+\tau_{i}+\varepsilon_{i j}
$$

$Y_{i j}=$ Observation of the second treatment effect and test $j$;

$\mu=$ General average value;

$\tau_{i}=$ Effect of treatment $i$;

$\varepsilon_{i j}=$ Test error due to maintenance and test $j$.

Hypothesis statistics tested:

$$
\mathrm{H}_{0}: \tau_{1}=\tau_{2}=\tau_{3}=0
$$

There was no effect on the treatment of the growth test of $L$. acidophilus bacteria on liquid medium.

$\mathrm{H}_{1}$ : There is at least one $\tau \neq 0$;

There is an effect of the treatment of the growth test of L. acidophilus bacteria on liquid medium.

The data obtained were tested using ANOVA at $5 \%$ level. If there was a real effect and treatment $\mathrm{H}_{1}$ was accepted, then it was followed by Duncan's multiple range test [16]. The test criteria used for statistical analysis were as follows:

$F$ count $<F$ table (0.05), $\mathrm{H}_{0}$ accepted and $\mathrm{H}_{1}$ rejected; $F$ count $\geq F$ table $(0.05), \mathrm{H}_{0}$ rejected and $\mathrm{H}_{1}$ accepted.

\section{Results and Discussion}

The results of the study of fructooligosaccharide (FOS) content in garlic and the effect of FOS from garlic on the growth of L. acidophilus bacteria are presented in Tables- 1 and 2.

The results of this study (Table-1) indicate that the FOS content in garlic was $3.34 \% \mathrm{~b} / \mathrm{b}$. This is consistent 
with the study of Altuntas and Korukluoglu [17], which reported that FOS is preferred and fermented by Lactobacillus and Bifidobacterium. FOS and galactooligosaccharides are a blend of the composition of oligosaccharides (medium-chain carbohydrates) [18]. FOS compounds are found in fruits and vegetables, including onion tubers, such as garlic (1-2\%) [19].

The results of this study (Figure-1) show that the optimal level of garlic in sample B $(4 \mathrm{ml})$ has a very significant effect $(p<0.05)$ compared to that of the control, A, C, and D samples. This is consistent with Lopes et al. [20], who reported that with the addition of foods containing prebiotics such as oligosaccharides, the composition of Lactobacillus spp., increased by $81 \%$. Supplementation with prebiotics at $0.1-0.2 \%$ can increase beneficial bacteria and reduce detrimental populations [12].

\section{Acidity}

This study (Table-2) shows that the growth of L. acidophilus with $\mathrm{pH} 2$ and $\mathrm{pH} 4$ in sample $\mathrm{B}(4 \mathrm{ml}$ of synbiotic) had a very significant effect $(\mathrm{p}<0.05)$ compared to the control, A $(2 \mathrm{ml}), \mathrm{C}(6 \mathrm{ml})$, and D $(8 \mathrm{ml})$ samples, so it can be said that Lactobacillus is resistant to acid and able to survive in $\mathrm{pH} 2$ low $\mathrm{pH}$ conditions. According to Gupta and Sharma [21], enzymes affect the growth of LAB at low $\mathrm{pH}$. The

Table-1: Results of testing for FOS content in garlic.

\begin{tabular}{lccl}
\hline Test parameters & Results & Unit & Method \\
\hline FOS & 3.34 & $\% \mathrm{~b} / \mathrm{b}$ & $\mathrm{HPCL}$ \\
\hline
\end{tabular}

FOS=Fructooligosaccharide

Table-2: Potential of garlic as a prebiotic against bile acids, bile salts, temperature, and feed (log CFU/ml).

\begin{tabular}{lccccc}
\hline Treatment & \multicolumn{3}{c}{ Synbiotic garlic } & \multirow{2}{*}{ Control } \\
\cline { 2 - 5 } & $\mathbf{A}$ & $\mathbf{B}$ & $\mathbf{C}$ & $\mathbf{D}$ & \\
\hline Bile salt & $9.97^{\mathrm{b}, \mathrm{c}}$ & $10.42^{\mathrm{a}}$ & $10.08^{\mathrm{b}}$ & $9.83^{\mathrm{c}, \mathrm{d}}$ & $9.78^{\mathrm{c}, \mathrm{d}}$ \\
Bile acid & $8.76^{\mathrm{b}}$ & $8.96^{\mathrm{a}}$ & $8.76^{\mathrm{b}}$ & $8.74^{\mathrm{b}}$ & $8.74^{\mathrm{b}}$ \\
Feed & $8.93^{\mathrm{b}}$ & $9.38^{\mathrm{a}}$ & $8.91^{\mathrm{b}}$ & $8.81^{\mathrm{b}}$ & $8.86^{\mathrm{b}}$ \\
\hline
\end{tabular}

$a, b, c, d$ Superscripts in the column show significant $(p<0.05)$

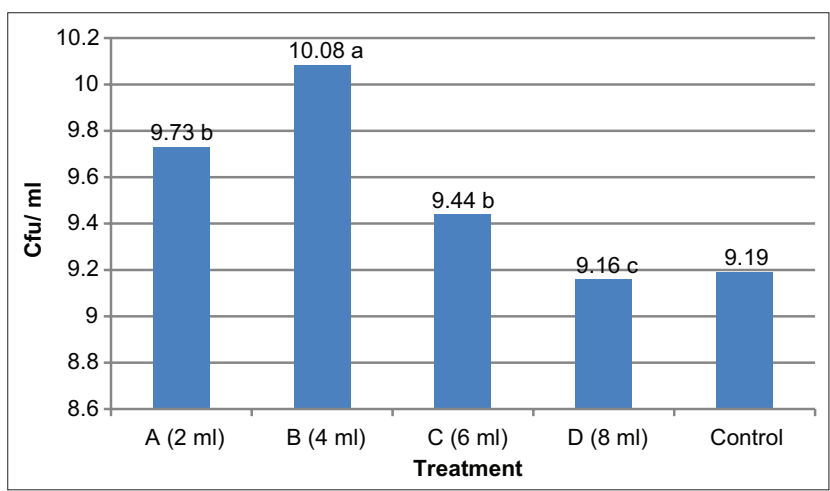

Figure-1: Optimal level of garlic. a,bSuperscripts in the line show significant $(p<0.05) . A=$ Extract of $2 \mathrm{ml}$ of garlic, $B=$ Extract of $4 \mathrm{ml}$ of garlic, $C=$ Extract of $6 \mathrm{ml}$ of garlic, $\mathrm{D}=$ Extract of $8 \mathrm{ml}$ of garlic. enzymes that affect the resistance of LAB at low $\mathrm{pH}$ levels are protease enzymes. Furthermore, it is said that the higher the protease enzyme possessed by an isolate, the more it can increase its resistance to acidic conditions. One of the protease enzymes, aminopeptidase, can affect the adaptation and growth of LAB isolates under acidic conditions [22]. This situation is not beneficial for pathogenic microorganisms. Damayanti et al. [23] argued that LAB can survive acid damage due to the presence of histidine decarboxylase enzymes and deimination of arginine enzymes. These results indicate that only a few isolates of the LAB tested can pass through the acidic gastric tract. The tolerance of LAB to acid is quite high due to its ability to maintain cytoplasmic $\mathrm{pH}$ at a higher alkalinity than the extracellular $\mathrm{pH}$ [13]. This is because if probiotics enter the digestive tract, they must survive the acidic conditions of the stomach, where the $\mathrm{pH}$ is around 2 [24]. According to Jiang et al. [25], the $\mathrm{HCl}$ concentration is $0.2-0.5 \%$, reducing the gastric $\mathrm{pH}$ to 1 if it is completely empty. $\mathrm{LAB}$ resistance to $\mathrm{pH}$ is low due to their ability to maintain an internal $\mathrm{pH}$ more alkaline than the external $\mathrm{pH}$ and by having cell membranes that are more resistant to cell leakage due to low $\mathrm{pH}$ [26]. The sensitivity of bacteria to acids can depend on the simultaneous work of other additional factors, such as water activity, salinity, redox potential, and heat treatment [27].

\section{Bile salts}

The observation (Table-2) shows that L. acidophilus cells can grow and survive in bile salts with a concentration of $0.3 \%$, and $0.6 \%$ in sample B ( $4 \mathrm{ml}$ of synbiotic) has a very significant effect $(\mathrm{p}<0.05)$ compared to that of the control, A $(2 \mathrm{ml}), \mathrm{C}(6 \mathrm{ml})$, and $\mathrm{D}(8 \mathrm{ml})$ samples. To see the resistance of LAB to bile salts can be seen from the number of log differences in the number of bacterial colonies, which, according to Vecchione et al. [28], observations of resistance to bile salts were calculated based on the difference in the unit log number of colonies grown in control conditions with bile salt treatments. The smaller the resistance, the more strains are tested against bile salts. The results of the study are in accordance with those of O'Flaherty et al. [29], which suggested that probiotics are living microorganisms that enter in sufficient quantities so that they can provide health benefits for the host. The sufficient amount stated by the Food and Agriculture Organization of the United Nations and the World Health Organization is $10^{6}-10^{8} \mathrm{CFU} / \mathrm{g}$. Live probiotics must be able to survive in unfavorable conditions, such as exposure to stomach acid and bile salt, and maintain their physiological activities [30].

\section{Total growth of LAB in feed}

The results of the study (Table-2) showed that the addition of garlic can significantly increase $(\mathrm{p}<0.05)$ the growth of L. acidophilus LAB on artificial ration feed, namely, in sample B (4 ml synbiotic). 
This is in accordance with the study of Georgieva et al. [31], which found that that the viability (resistance) of L. acidophilus in factory chicken feed can survive so that chicken feed containing these microorganisms is used. Because chicken feed containing microorganisms has a lifespan or a time limit till expiration, which is characterized by the death of microorganisms in chicken feed. If the microorganisms in the feed are dead, then the feed is no longer able to inhibit pathogenic bacteria. According to Javanmard et al. [32], the growth and survival of organisms are reduced due to the limited food or nutritional supply. Under limited food conditions, the number of organisms will decline quickly. Indeed, cell death is greater than cell proliferation [33]. This is in accordance with Paulina Markowiak and Śliżewska [34], who reported that the declining growth rate occurs because mortality increases, reproduction decreases, or both occur. According to Tokatl et al. [35], this situation shows that there is competition among bacteria for nutrition and space. It is also caused by the presence of cells that are added to the medium. According to Lee et al. [18], in some circumstances, it can be followed by the lysis of cells so that the turbidity and number of cells directly calculated will decrease in line with the reduction of living cells. There is further inhibition of metabolite products and important nutrients in the depleted medium.

\section{The amount of $L$. acidophilus bacteria at different temperatures}

Data in this study (Table-3) showed that $L$. acidophilus had the highest amount of growth in sample $B$, which had a very significant effect $(p<0.05)$ with the control, C, and D samples, but was not significantly different from sample A at different temperatures. This is in accordance with Schloss [36], who reported that the higher the temperature given, the smaller the activity or possibility of live bacteria. This is because the temperature can affect microorganisms in two opposite ways: (1) When the temperature rises, the speed of metabolism rises and growth is accelerated. Conversely, when the temperature drops, the speed of metabolism also decreases and growth is slowed. (2) If the temperature rises or falls, the growth rate may stop, the cell components become inactive, and cells can die. According to Fernández et al. [2], this occurs because lactic acid, as a short-chain fatty acid, is also used as a carbon source by $L$. acidophilus for its growth through metabolic pathway $\beta$-oxidation such that lactic acid metabolism is directly used as a source of nutrition by L. acidophilus, thereby increasing bacterial growth.

\section{The amount of $L$. acidophilus bacteria against storage time}

Based on Table-4, it is known that the storage time that feeds could maintain the amount of bacteria in sample B was significantly different $(p<0.05)$ than that in the control, $\mathrm{C}$, and D samples, but not
Table-3: The amount of Lactobacillus acidophilus bacteria at different temperatures.

\begin{tabular}{lcccc}
\hline \multirow{2}{*}{ Treatment } & \multicolumn{4}{c}{ Temperature resistance } \\
\cline { 2 - 5 } & $\mathbf{5 0 ^ { \circ } \mathbf { C }}$ & $\mathbf{6 0}^{\circ} \mathbf{C}$ & $\mathbf{7 0}^{\circ} \mathbf{C}$ & $\mathbf{8 0}^{\circ} \mathbf{C}$ \\
\hline A $(2 \mathrm{ml})$ & $7.92^{\mathrm{a}}$ & $7.94^{\mathrm{a}}$ & $7.87^{\mathrm{a}, \mathrm{b}}$ & $8.01^{\mathrm{a}, \mathrm{b}}$ \\
B $(4 \mathrm{ml})$ & $8.00^{\mathrm{a}}$ & $8.10^{\mathrm{a}}$ & $8.00^{\mathrm{a}}$ & $8.19^{\mathrm{a}}$ \\
C $(6 \mathrm{ml})$ & $7.77^{\mathrm{b}}$ & $7.76^{\mathrm{b}}$ & $7.74^{\mathrm{b}}$ & $7.82^{\mathrm{b}}$ \\
D $(8 \mathrm{ml})$ & $7.77^{\mathrm{b}}$ & $7.75^{\mathrm{b}}$ & $7.74^{\mathrm{b}}$ & $7.86^{\mathrm{b}}$ \\
Control & $7.75^{\mathrm{b}}$ & $7.76^{\mathrm{b}}$ & $7.75^{\mathrm{b}}$ & $7.80^{\mathrm{b}}$ \\
\hline
\end{tabular}

a,b Superscripts in the column show significant $(p<0.05)$

Table-4: The amount of Lactobacillus acidophilus bacteria against storage time.

\begin{tabular}{lcccc}
\hline Treatment & \multicolumn{4}{c}{ Storage time } \\
\cline { 2 - 5 } & 1 day & 2 days & 3 days & 4 days \\
\hline A $(2 \mathrm{ml})$ & $7.92^{\mathrm{a}, \mathrm{b}}$ & $7.88^{\mathrm{a}, \mathrm{b}}$ & $7.91^{\mathrm{a}, \mathrm{b}}$ & $8.05^{\mathrm{a}}$ \\
$\mathrm{B}(4 \mathrm{ml})$ & $7.98^{\mathrm{a}}$ & $8.00^{\mathrm{a}}$ & $8.05^{\mathrm{a}}$ & $8.25^{\mathrm{a}}$ \\
C $(6 \mathrm{ml})$ & $7.80^{\mathrm{b}}$ & $7.76^{\mathrm{b}}$ & $7.78^{\mathrm{b}}$ & $7.78^{\mathrm{b}}$ \\
$\mathrm{D}(8 \mathrm{ml})$ & $7.78^{\mathrm{b}}$ & $7.83^{\mathrm{b}}$ & $7.84^{\mathrm{b}}$ & $7.82^{\mathrm{b}}$ \\
Control & $7.77^{\mathrm{b}}$ & $7.76^{\mathrm{b}}$ & $7.77^{\mathrm{b}}$ & $7.77^{\mathrm{b}}$ \\
\hline
\end{tabular}

a,b Superscripts in the column show significant $(p<0.05)$

significantly different from sample A at 1, 2, 3, and 4 days storage periods. This is presumably because the LAB population increases with the length of storage time, provided that bacteria get nutritional support to maintain their metabolism and are provided with the right conditions for growing bacteria; Lactobacillus, for example, live at optimum temperatures of $30^{\circ} \mathrm{C}$ under anaerobic conditions (no need for $\mathrm{O}_{2}$ free) [37]. Table-4 shows that the population of LAB increases in population along with the storage time of the biotic feed and temperature; the optimal temperature for bacterial growth is room temperature above $50^{\circ} \mathrm{C}$. According to Amalia et al. [38], the time between each microbial cell division ranges from 10 to $60 \mathrm{~min}$. According to Yang et al. [39], the optimum temperature for the growth of LAB varies in each strain. The LAB Bacillus subtilis belongs to the class of mesophilic bacteria whose optimum temperature is $25^{\circ} \mathrm{C}$ and maximum temperature is $40^{\circ} \mathrm{C}$.

\section{Conclusion}

For the addition of garlic as a prebiotic with L. acidophilus, which can be used as a synbiotic, $4 \mathrm{ml}$ of extract is the most effective at increasing the growth of $L$. acidophilus, acid and bile salt resistance, feed viability, temperature resistance, and feed storage time.

\section{Authors' Contributions}

PS performed research to completion, data analysis, and scientific article writing. DS, LDM, and VDY performed data analysis, drafted and revised the manuscript. All authors read and approved the final manuscript.

\section{Acknowledgments}

Thanks to the Research Ministry, Technology and Higher Education of the Republic of Indonesia 
who helped carry out this research through doctoral dissertation research grants and the Domestic Postgraduate Education Scholarship Program (BPP-DN DIKTI), Contract no. 258-41/UNJ.P4.3/PP/2019.

\section{Competing Interests} interests.

The authors declare that they have no competing

\section{Publisher's Note}

Veterinary World remains neutral with regard to jurisdictional claims in published institutional affiliation.

\section{References}

1. Gilchrist, M.J., Greko, C., Wallinga, D.B., Baran, G.W., Riley, D.G. and Thorne, P.S. (2014) The potential role of concentrated animal feeding operations in infectious disease epidemics and antibiotic resistance. Environ. Health Perspect., 115(2): 313-316.

2. Fernández, J., Redondo-Blanco, S., Gutiérrez-del-Río, I., Miguélez, E.M., Villar, C.J. and Lombó, F. (2016) Colon microbiota fermentation of dietary prebiotics towards shortchain fatty acids and their roles as anti-inflammatory and antitumor agents: A review. J. Funct. Foods, 25: 511-522.

3. Mansouri, E., Milani, E., Sani, A.M. and Nourbakhsh, L. (2016) Viability of Bifidobacterium bifidum and Escherichia coli in versus prebiotic effects of Jerusalem artichoke (Helianthus tuberosus). Zahedan J. Res. Med. Sci., 18(11): e3771.

4. Kareem, K.Y., Ling, F.H., Chwen, L.T., Foong, O.M., Asmara, S.A., Akit, H., Abdulla, N.S. and Ooi, M.F. (2015). Carcass, meat and bone quality of broiler chickens fed with postbiotic and prebiotic combinations. Int. J. Probiotics Prebiotics, 10(1): 23-30.

5. Rahman, S.U. Khan, S., Chand, N., Sadique, U. and Khan, R.U. (2017) In vivo effects of Allium cepa. L. on the selected gut microflora and intestinal histomorphology in broilers. Acta Histochem., 119(5): 446-450.

6. Clavijo, V. and Flórez, M.J.V. (2018) The gastrointestinal microbiome and its association with the control of pathogens in broiler chicken production: A review. Poult. Sci., 97(3): 1006-1021.

7. Zhang, T., Yang, Y., Liang, Y., Jiao, Z. and Zhao, C. (2018) Review the beneficial effect of intestinal fermentation of natural polysaccharides. Nutrients, 10(8): 1055.

8. Murat, A.T., Taban, S., Taban, N. and Yimaz, E.L. (2017) Characterization of garlic (Allium sativum L.) according to the geographical origin by analysis of minerals. Fresenius Environ. Bull., 26(6): 4292-4298.

9. Atsamnia, D., Hamadache, M., Hanini, S., Benkortbi, O. and Oukrif, D. (2017) Prediction of the antibacterial activity of garlic extract on E. coli, S. aureus and B. subtilis by determining the diameter of the inhibition zones using artificial neural networks. LWT Food Sci. Technol., 82: 287-295.

10. Ibrahim, E.A. (2017) In vitro Antimicrobial activity of Allium sativum (Garlic) against wound infection pathogens. Afr. J. Med. Sci., 2(8): 666-669.

11. Adebiyi, F.G., Ologhobo, A.D. and Adejumo, I.O. (2017) Efficacy of Allium sativum as growth promoter, immune booster and cholesterol-lowering agent on broiler chickens. Asian J. Anim. Sci., 11(5): 202-213.

12. Machado, M.T.C., Kaliana, S.E., Vieira, G.S., Menegalli, F.C., Martínez, J. and Hubinger, M.D. (2015) Prebiotic oligosaccharides from artichoke industrial waste: Evaluation of different extraction methods. Ind. Crops Prod., 76: 141-148.

13. Saiz, N.V., Belguesmia, Y., Raspoet, R., Auclair, E., Gancel, F., Kempf, I. and Drider, D. (2019) Benefits and inputs from lactic acid bacteria and their bacteriocins as alternatives to antibiotic growth promoters during food animal production. Front. Microbiol., 10: 57.

14. Balasingham, K., Valli, C., Radhakrishnan, L. and Balasuramanyam, D. (2017) Probiotic characterization of lactic acid bacteria isolated from swine intestine. Vet. World, 10(7): 825-829.

15. Bin Masalam, M.S., Bahieldin, A., Alharbi, M.S., Al-Masaudi, S., Al-Jaouni, S.K., Harakeh, S.M. and Al-Hindi, R.R. (2018) Isolation, molecular characterization and probiotic potential of lactic acid bacteria in Saudi Raw and fermented milk. Evid. Based Complement. Altern. Med., 2018(12): 7970463.

16. Gherezgihier, G.A., Mahmud, A., Samuel, M. and Tsighe, N. (2017) Methods and application of statistical analysis in food technology. J. Acad. Ind. Res., 6(5): 78-84.

17. Altuntas, S. and Korukluoglu, M. (2019) Growth and effect of garlic (Allium sativum) on selected beneficial bacteria. Food Sci. Technol. Campinas, 39(4): 897-904.

18. Lee, J.H., Lee, J., Whang, J., Nam, J.S., Lee, J., Kim, S.M., Han, H.K., Choi, Y., Kim, S.N. and Kim, H.R. (2016) Changes in nutritional components of the northern and southern types garlic by different heat treatments. Korean $J$. Food Cookery Sci., 32(3): 245-252.

19. Dixit, S., Dube, H.V., Dubey, A.K. and Singh, V.P. (2018) Yield and nutrient uptake of garlic (Allium sativum L.) as influenced by sulfur nutrition. J. Pharmacogn. Phytochem., 7(2): 1961-1963.

20. Lopes, S.M.S., Francisco, M.G., Higashi, B., deAlmeida, R.T.R., Krausová, G., Pilau, E.J., Goncalves, J.E., Goncalves, R.A.C. and de Oliveira, A.J.B. (2016) Chemical characterization and prebiotic activity of fructooligosaccharides from Stevia rebaudiana (Bertoni) roots and in vitro adventitious root cultures. Carbohydr. Polym., 152: 718-725.

21. Gupta, A. and Sharma, N. (2017) Characterization of potential probiotic lactic acid bacteria Pediococcus acidilactici Ch-2 isolated from Chuli a traditional apricot product of Himalayan region for the production of novel bioactive compounds with special therapeutic properties. J. Food Microbiol. Saf. Hyg., 2(1): 119.

22. Hill, D., Sugrue, I., Tobin, C., Hill, C., Stanton, C. and Ross, R.P. (2018) The Lactobacillus casei group: History and health-related applications. Front. Microbiol., 9: 2107.

23. Damayanti, E., Istiqomah, L., Saragih, J.E., Purwoko, T. and Sardjono, S. (2017) Characterization of lactic acid bacteria as poultry probiotic candidates with aflatoxin B1 binding activities. IOP Conf. Ser. Earth Environ. Sci., 101(1): 012030.

24. de Souzaa, L.F.A., Araújob, D.N., Stefania, L.M., Giomettia, I.C., Cruz-Polycarpoc, V.C., Polycarpoc, G. and Burbarellid, M.F. (2018) Probiotics on performance, intestinal morphology and carcass characteristics of broiler chickens raised with lower or higher environmental challenge. Aust. J. Vet. Sci., 50(1): 35-41.

25. Jiang, T., Li, H.S., Han, G.G., Singh, B., Kang, S.K., Bok, J.D., Kim, D.D., Hong, Z.S., Choi, Y.J. and Cho, C.S. (2017) Oral delivery of probiotics in poultry using $\mathrm{pH}$-sensitive tablets. J. Microbiol. Biotechnol., 27(4): 739-746.

26. Wang, Y., Sun, J., Zhong, H., Li, N., Xu, H., Zhu, Q. and Liu, Y. (2017) Effect of probiotics on the meat favor and gut microbiota of chicken. Sci. Rep., 7: 6400.

27. Dec, M., Nowaczek, A., Stępień-Pyśniak, D., Wawrzykowski, J. and Chmiel, R.U. (2018) Identification and antibiotic susceptibility of lactobacilli isolated from turkeys. BMC Microbiol., 18(1): 168.

28. Vecchione, A., Celandroni, F., Mazzantini, D., Senesi, S., Lupetti, A. and Ghelardi, E. (2018) Compositional quality and potential gastrointestinal behavior of probiotic products commercialized in Italy. Front. Med., 5: 59.

29. O'Flaherty, S., Crawley, A.B., Theriot, C.M. and Barrangou, R. (2018) The Lactobacillus bile salt hydrolase repertoire reveals niche-specific adaptation. mSphere, 3(3): e00140-18.

30. Khalil, E.S., Abd Manap, M.Y., Mustafa, S., Alhelli, A.M. 
and Shokryazdan, P. (2018) Probiotic properties of exopolysaccharide producing Lactobacillus strains isolated from tempoyak. Molecules, 23(2): 398.

31. Georgieva, M., Andonova, L., Peikova, L. and Zlatkov, A. (2014) Probiotics health benefits, classification, quality assurance and quality control review. Pharmacia, 61(4): 22-31.

32. Javanmard, A., Ashtari, S., Sabet, B., Davoodi, S.H., Rostami-Nejad, M., Akbari, M.E., Niaz, A. and Mortazavian, A.M. (2018) Probiotics and their role in gastrointestinal cancers prevention and treatment; an overview. Gastroenterol. Hepatol. Bed Bench, 11(4): 284-295.

33. Wasilewski, A., Zielinska, M., Storr, M. and Fichna, J. (2015) Beneficial effects of probiotics, prebiotics, synbiotics, and psychobiotics in inflammatory bowel disease. Inflamm. Bowel Dis., 21(7): 1674-1682.

34. Markowiak, P. and Śliżewska, K. (2018) The role of probiotics, prebiotics and synbiotics in animal nutrition. Gut Pathog., 10: 21.
35. Tokatl, M., Gülgör, G., Elmacı, S.B., İşleyen, N.A. and Özçelik, F. (2015) In vitro properties of potential probiotic indigenous lactic acid bacteria originating from traditional pickles. BioMed Res. Int., 2015(8): 315819.

36. Schloss, P.D. (2014) Microbiology: An integrated view of the skin microbiome. Nature, 514(7520): 44-45.

37. Kim, S.A., Jang, M.J., Kim, S.Y., Yang, Y., Pavlidis, H.O. and Ricke, S.C. (2019) Potential for prebiotics as feed additives to limit foodborne Campylobacter establishment in the poultry gastrointestinal tract. Front. Microbiol., 10: 91.

38. Amalia, U., Sumardianto, S., and Agustini, T.W. (2017) Characterization of Lactic Acid Bacteria (LAB) isolated from Indonesian shrimp paste. IOP Conf. Ser. Earth Environ. Sci., 116(1): 012049.

39. Yang, E., Fan, L., Yan, J., Jiang, Y., Doucette, C., Fillmore, S. and Walker, B. (2018) Influence of culture media, $\mathrm{pH}$ and temperature on growth and bacteriocin production of bacteriocinogenic lactic acid bacteria. AMB Express, 8(1): 10.

$* * * * * * * *$ 